\title{
Inflation Targeting in Practice: A Survey
}

\author{
Kameliia Petrova \\ School of Business and Economics, State University of New York \\ 101 Broad Street, Plattsburgh, NY 12901, USA \\ Tel: 1-518-564-4187 E-mail: kpetr001@plattsburgh.edu
}

$\begin{array}{ll}\text { Received: December 12, } 2011 & \text { Accepted: January 29, } 2012 \quad \text { Published: March 16, } 2012 \\ \text { doi:10.5539/ijbm.v7n6p58 } & \text { URL: http://dx.doi.org/10.5539/ijbm.v7n6p58 }\end{array}$

\begin{abstract}
Since its first introduction in New Zealand in 1990, inflation targeting has been successfully adopted in several industrialized countries-Canada, the United Kingdom, Sweden, Finland, Australia in the early 1990s; and Iceland and Norway a decade later. More recently, several emerging market economies (Mexico, Israel, Chile, and Brazil among them) have tried to move in the same direction. I have performed a cross-country comparison of the application of inflation targeting framework. Reviewing case studies and empirical evidence from the past twenty years, I present and summarize the most recent results and practical issues experienced by the emerging market economies, as well as the necessary steps that should be considered to ensure a successful implementation.
\end{abstract}

Keywords: Inflation targeting, Monetary policy

\section{Introduction}

One of the most interesting phenomena in the area of monetary policy in the past twenty years has been the adoption of inflation targeting (IT hereafter) (Bernanke and Mishkin, 1997; Clarida et al., 1999; Clarida et al., 2000; Bernanke et al., 1999; Svensson, 2007; Walsh, 2008). Though it has a relatively short history IT proved to be a promising monetary policy tool for the countries who have adopted it (Masson et al., 1997; Blejer et al., 2000; Walsh, 2008). IT has successfully solved problems caused by lack of credibility, among other things. It is worth mentioning that IT has not been spared from a certain level of controversy. Opinions among macroeconomists range from those who believe that adopting IT would be the best way to keep inflation at bay (Bernanke and Mishkin, 1997; Mishkin, 2004); to those who disapprove of IT (Friedman, 2004; Stiglitz, 2008). The goal of this paper is to present a cross-country comparison of the outcomes achieved by Central Banks who have adopted IT over the past twenty years. In the process, conclusions about practical problems and challenges presented from the application of IT are discussed.

In the first part of the paper, I discuss the theoretical aspects of IT. While relatively straightforward from a theoretical point of view, the practical application of IT needs more detailed attention. For example, a successful implementation of IT involves two requirements - independence of the Central Bank to choose policy instruments and a concentration of the policy on the target. A framework (or a rule) has to be decided upon and clarified beforehand. It is incorrect to describe inflation targeting as "an ironclad" policy rule. Rather, it is a policy framework with a specific target, playing the role of a nominal anchor in the long-run that provides opportunities for achieving other short-run objectives (Clarida et al., 2000; Bernanke et al., 1999). Output stabilization could be such an objective.

The second part of the paper discusses some operational aspects of the adoption of IT. The Central Bank should decide on the horizon of the target, the price level and the width of the band, as well as some specific procedures to guarantee the transparency of the regime (Bernanke and Mishkin, 1997). An interesting question is how the Central Bank implements the inflation forecasts into the targeting framework. Some common features and the economic performance of the IT countries are summarized.

The last part of the paper deals with the problems of implementing IT in developing countries. It stresses what problems they face, how they benefit, and presents some interesting empirical results from the literature. There are some countries where adoption of IT is impossible without a broad stabilization and a reduction of fiscal dependence. The majority of developing countries can be divided in two groups depending on which of the two prerequisites for a successful implementation of IT, mentioned above, is seriously violated. Some countries have 
achieved very good results in the adoption of IT (Israel and Chile for example). Interesting details regarding the process of the adoption of IT framework in Chile, Israel, Poland, Mexico, Korea and the Philippines are presented.

\section{Theoretical Base}

IT has been defined in the literature as a monetary policy framework adopted by the Central Bank to achieve price stability (Bernanke and Mishkin, 1997; Bernanke et al., 1999; Bernanke and Woodford, 2005). The Central Bank and the Government announce an explicit quantitative target of inflation to be achieved during a specified time horizon (Debelle, 1997; Clarida et al., 1999; Clarida et al., 2000). In what follows, the Central Bank forecasts future inflation and periodically compares the result of the forecast with the target. When differences occur, the Central Bank makes an independent adjustment in the monetary policy instrument and is required to provide public information about its decisions (Svensson, 1997, 1999). Such transparency increases the Central Bank's credibility and accountability.

There are several points of interest in the above theoretical definition. IT can be viewed in the light of the traditional rule vs. discretion dichotomy. Svensson (1999) and Bernanke and Mishkin (1997) describe IT as a "constrained discretion." It works by setting the goals and the framework for implementing monetary policy, while leaving the independence of choosing the instruments to the Central Bank. While popular and widely adopted, this view has been questioned by McCallum (1997b, 2000), who proposes an alternative monetary approach. This approach is based on a period-by-period optimization of a particular reaction function, as a way to achieve the goals and avoid the inflationary bias that characterizes the discretionary policy.

To have such policy working, the Central Bank needs at least a "partial independence" to set up the monetary instruments (McCallum, 1997a). An important difference should be noted. While the "instrument independence" is a prerequisite, it does not necessarily mean goal independence, but a separation of the monetary and fiscal policy (White, 2007). In other words, the borrowing of the Government from the Central Bank should be very low. Further, the Government should not have to rely on revenues from seigniorage (issuing money), rather it must have a stable revenue base to rely on.

Another important requirement is the willingness of the monetary authorities to "avoid targeting of additional objectives". Wages and nominal exchange rates are typical examples. Leiderman and Svensson (1995) show that theoretically this is possible only if "the inflation target has priority;" but practically, this "coexistence of targets could be problematic, since the authorities are not able to convince the public in advance about these priorities". The result of targets coexistence is violation of the policy credibility. An important question arises, then, about the relationship between IT and output stability. Ben Bernanke, who supports IT policies, believes that IT does not have to come at the expense of output stabilization (Bernanke and Mishkin, 1997). Clarida, et al., (1997) show that there is a trade-off between output and inflation. Debelle (2000) argues that the difference in the lags between the impact of the change of the interest rate on output and inflation gives rise to a trade-off in the case of demand shock, since the change in the interest rate first affects output and then affects inflation indirectly through the effect on the output gap. In the case of supply shock, output remains at the potential level and inflation increases. A trade-off still exists, since a negative output gap is required to return inflation to the target rate. As a result, demand shocks and small supply shocks can be accommodated, while large negative supply shocks, resulting in large increase of prices and inflation rate, require some trade-off between inflation and output variability (McCallum, 2007).

IT permits a degree of policy discretion in the short-run that allows the Central Bank to respond to the current economic dynamics (Bernanke et al, 1999). This short-run flexibility requires that the public's expectations of inflation remain stable. This allows for the medium and long-term inflation goals of the Central Bank to remain credible. Transparency is an important element in implementing IT policy (Jonas and Mishkin, 2003; Arndt, 2006; McCallum, 2007; Walsh, 2009). It is more efficient when markets understand the objectives and the links between monetary policy measures and these objectives. Proponents of IT claim that this approach maximizes transparency, since it is easier for the public to understand the explicit announcements of the targets than to understand the growth of a particular monetary aggregate. Because of the importance of the variability of inflation, reducing uncertainty about the future path of inflation can help by improving savings and investments, increasing the productivity growth as a result, as well as reducing the volatility of the financial markets (Bernanke and Woodford, 2005).

The rationale behind the adoption of an IT framework can be summarized as follows. The cost of high inflation has been broadly documented in the literature (Nakamura and Steinsson, 2008), and so was the fact that using monetary policy instruments to achieve other goals in the short run does produce successful results (Googfriend, 
2000). Unemployment and output, however, belong to a special category of short term goals, because they are consistent with the IT framework (Clarida et al., 1999). This follows theoretically because monetary policy can influence only nominal variables in the long run. In other words, unemployment and output can be dealt with.

The second rationale, argue Leiderman and Svensson (1995), is that a credible commitment to an inflation target can avoid the inflation bias of monetary policy under discretion. They show that such monetary policy can result in a higher than the optimal inflation rate. One possible reason could be that the unemployment is below the natural rate. A Central Bank operating under an IT framework with a properly defined objective function has no incentive to conduct such policy.

\section{Operational Aspects of Inflation Targeting}

The announcement of the inflation target varies across countries. Though being a purely technical detail, it nevertheless deserves mentioning. In Australia, Finland and Sweden (Blejer et al., 2000; Debelle, 2000) the Central Bank announced the inflation target. In Canada and New Zealand (Blejer et al., 2000; Freedman, 2000; Arecher, 2000; White, 2008; Koeppl, 2009) it resulted from a joint agreement between the Central Bank and the Government. In most of the cases the Government subsequently endorsed the regime.

Setting up the horizon of the target depends on the inflation at the moment of adoption of the policy. Canada and New Zealand started with an 18 month horizon to reach the target. They then set up the targets for a further reduction every 12 months in New Zealand and every 18 months in Canada. Once inflation was reduced, both countries set up the target in 5 years. In the UK (Haldane, 1998; Blejer, 2000) the horizon was first set up until the end of the parliamentary term (mid 1997) with a band of 1-4\%. In Australia the horizon was the length of the business cycle.

The determination of the target is a crucial moment. As can be seen from Table 1, all IT countries have chosen CPI, excluding some of its components. Only Sweden and Spain (Masson, 1997) target CPI in its basic variant. The Central Bank is obliged to make clear the reason for choosing any particular level as a target. Table 1 again shows that the target was set at $4 \%$ or less in all developed countries. Bernanke and Mishkin (1997) provide a good explanation of what the ideal range might be. They argue that as soon as inflation is an endogenous variable, any variation in inflation is connected with factors such as supply shocks and political instability. This means that the choice of target is based predominantly on some "prior arguments, intuition and indirect evidence". They also discuss the problem of the lowest possible target, pointing out that a zero inflation target (or close to zero) is not desirable and review some of the possible reasons. The conclusion is that inflation rate should be set above zero.

The width of the band around the target is a major difference across the countries. In Australia and Finland (Table 1), the authorities chose a particular point target, while Canada, New Zealand, Sweden and the UK specified a range for the target. In Spain, the target is determined in terms of ceiling for the inflation rate. The choice of bandwidth is considered to be an important detail, since it reflects the trade-off between announcing a tight and a wide band. It is very possible to breach a tight band, which can damage the credibility of the Central Bank. On the other hand, setting up a wide band can be viewed as "softness" of the policy of the Central Bank.

One of the basic characteristics of the IT regimes is their transparency and accountability. The Central Banks explain their policy in regular Inflation Reports or Monetary Policy Statements. A good description of how this is organized across countries is provided by Svensson (1997). For example, the Reserve Bank of New Zealand, Bank of England and Sveriges Riskbank publish graphs of the conditional inflation forecasts. The Bank of England publishes the minutes of the meetings of the Monetary Policy Committee within six weeks. Why does this scheme work? As Svensson points out, when the central bank is "explicit" about setting the target, it not only becomes very simple to assess the degree of achievement of the bank's objective, but more importantly, it provides an incentive for the Central Bank to follow through.

An accurate prediction of inflation is a very difficult task. Since there are lags in the effects of the monetary policy actions, this low predictability is a real obstacle to the IT. This immediately results in a damage of the credibility of the Central Bank. Still, there are some criteria that can be used in the process of forecasting. Sufficient historical data is needed for the estimation of relationships that can be viewed as relatively stable under the new regime. Debelle (1997) mentions that the expectation about the future path of inflation need not be based on a particular model. However, Bernanke and Woodford (1996) argue that the decisions of the Central Bank under an IT framework should be based on "explicit structural models of the economy". While targeting private-sector forecasts is not a good idea, they can be combined with the Central Bank's information to achieve some improvements in operational aspect. 
As a final note on the operational aspects of IT, I would like to bring about the observation made by Orphanides and Williams (2007) that "monetary policy rules that would perform well under the assumption of rational expectations can perform very poorly when we introduce imperfect knowledge." (See also Orphanides and Williams, $2004 \& 2006$ ) The authors use an estimated model of the US economy to study the performance of a monetary policy rule characterized by transparency, commitment to price stability and close monitoring of inflation expectations. Their analysis suggests that monetary policy strategies need to be robust to imperfect knowledge and caution against using IT goals formulated in terms of "gaps from natural rate concepts that are fundamentally unknowable." Orphanides and Williams (2007) also point out that the imperfect information problem is very often present in small open economies and economies in transition.

\section{Common Features Experienced by the Advanced Economies}

IT was adopted first in the early 1990s by seven industrialized countries - New Zealand, Canada, the United Kingdom, Finland, Sweden, Australia and Spain. The implemented regimes differ along many dimensions details of implementation, channels for communication between the Central Bank and the public on one side and the Government on the other, etc. One accepted approach in the literature is the case study analysis. Comprehensive analyses are presented in Leiderman and Svensson (1995) and Bernanke et al. (1999), as well as Debelle (1997) and Blejer et al. (2000).

Instead of providing an extensive description of all the characteristics across different countries and making a comparison, which is far beyond the scope of this paper, a much better approach is to summarize some common details, shared by all of them. This may coincide, to a degree, with the technical characteristics stated above, but is relevant to the discussion in the following section though, for the sake of completeness, Table 1 provides some important details.

Masson et al. (1997) group these common features in the following way:

- High flexibility of the exchange rate. In the UK, Sweden and Finland, inflation targeting was adopted after the failure of the exchange as a nominal anchor;

- All of the countries have a measure of the Central Bank independence, such as fiscal and instrument independence. The Central Bank uses the short-term interest rate as an instrument and well-developed markets to transmit the effects;

- The monetary policy is forward looking, since the Central Bank takes the responsibility to offset all the shocks' effects in the future over a horizon of 1-2 years;

- Inflation targeting is a device for building of credible monetary policy, in the sense that the public is informed, providing the transparency of inflation targeting. This enables the Central Bank to influence the public's expectations;

- Inflation targeting was introduced in all of the countries when the inflation rate was relatively low (less than $10 \%)$.

Bernanke and Mishkin (1997) include Germany and Switzerland as a "hybrid case of inflation-focused monetary policy". These two countries differ from the group of the economies with explicit inflation targeting, because they use monetary growth as a target, instead of inflation. The authors argue that "this distinction is overstated", since in both cases the same final goal is achieved. The main practical difference stems from the fact that these two countries are willing to implement money growth targeting, since the velocity of money has been more stable there. In general, the case of Germany and Switzerland is important, because they have consistently followed this policy for more than twenty years. The two countries' practice can be helpful in providing useful information about an alternative way of inflation-focused monetary policy.

\subsection{Economic performance under inflation targeting}

Inflation remains near the target rate in Australia and Finland, and close or within the range in Canada, New Zealand, the UK and Sweden. Since a general reduction of inflation is noticed even in the economies operating without an IT framework, it is still not that significant a result. However, during the period 1988-1992 IT countries managed to reduce inflation more than the other industrial countries, and to keep these levels close to theirs. This shows that IT has been useful for countries with problems related to the anti-inflation credibility of the Central Bank. The reduction of the inflation was accompanied by a higher rate of unemployment. Only New Zealand experienced a decline in unemployment in the 1990s. One comparison between IT countries and other industrialized countries shows that unemployment rose significantly in 1990s in the IT countries, but after 1994 it tended to be close to the levels of the other industrialized countries (Masson et al., 1997). In general, until 
1998 most of the countries with target bands managed to maintain inflation within the target.

\section{Inflation Targeting as a Framework for Monetary Policy in Developing Countries}

The promising results achieved by the industrialized countries, as well as the failure of the exchange rate bands as nominal anchors, have convinced some developing countries to implement IT. The first stage of the process is predetermined to be less formal, since all of them have practical difficulties and problems with adopting the policy in its clear variant. In Latin America, Brazil, Chile, Colombia, Mexico and Peru moved to a floating exchange rate regime. Some emerging economies, the Czech Republic, Poland, Hungary, Israel, South Africa and more recently Thailand, have conducted inflation targeting through a more or less formal process. Although it has been only a short period working under this framework, the results have been rather promising.

All these countries face two main questions on their way to adopting IT - first, conditions of formal adoption, and second, aspects of the monetary policy that are the appropriate for this regime. There is huge heterogeneity among developing countries. Although they might experience some common trends, they are at different stages of their development. The reforms have different speed. As a result, they have different experiences in conducting monetary policy.

Aninant (2000) points out that IT can benefit developing countries in many ways: by providing "a coordination device for inflation expectations, a yardstick of accountability for the Central Banks and a guide for the operational conduct of monetary policy, as well as by committing monetary authorities to sound fundamentals". It should be made clear, though, that developing countries have specific problems, which can make IT more difficult for them to implement than it is for the industrialized countries.

As mentioned above, there are two requirements for implementing IT - the Central Bank independence and adoption of no other nominal targets. There is a group of countries for which it is immediately obvious that the basic requirements are not satisfied. These are the countries with a very high rate of inflation - above $30 \%$ per annum. Under such circumstances, monetary policy has unpredictable effects. The main goal of the authorities is to reduce inflation radically through implementing stabilization programs, cutting government financing and choosing appropriate nominal anchors. Another extreme case is the countries in currency unions. They fix their nominal exchange rate to the currency of the main partner. In that way they accept the inflation rate of this partner. With the exception of these two extreme cases, for the majority of the developing countries it is difficult to assess the degree of consistency with the requirements for successful implementation of IT. It turns out that fiscal dominance is not that bad when the inflation rate is reduced to a moderate level. On the other hand, a common finding in all these countries is that the Central Bank operates in a totally different environment then the one in the advanced economies. There are three main factors that tend to be constraining for the Central Bankheavy reliance on seigniorage, shallow financial markets and a fragile banking system. Masson et al. (1997) provide a good comparison of estimates of revenues from seigniorage, rate of inflation and fiscal deficit for 79 countries from 1980 to 1995 . They found that the reliance on seigniorage is much higher in the developing (1.4-3\% of GDP) than in the industrialized countries (1\% of GDP). The relationship between fiscal deficit, inflation and seigniorage varies across regions and country groups. On average, reliance on seigniorage in the first seven developed countries that adopted IT in early 1990s was similar to that for all advanced economies. The average inflation performance in some middle-income developing countries (Indonesia, Korea, Israel, Mexico and South Africa) did not differ that much from that of the IT industrialized countries.

Depending on the level of development and the stage of implementation of stabilization reforms, different countries should follow different paths to achieve the conditions required for independence of the Central Bank. Most of them need broad public sector reforms, reduction of the seigniorage reliance and stabilization of the bank sector (Masson et al., 1997).

There is a group of high-income developing countries with relatively stable financial markets, low inflation and no fiscal dominance. The problem of adopting IT in these countries is not the lack of independence of the Central Bank, but the willingness to concentrate the attention on separate objectives, rather than on the inflation target only. Exchange rate regimes and capital mobility play quite a big role there. All of these, together with the lack of a reliable inflation forecasting and criteria for assessing the results, complicate the process even more.

In light of the above stated operational aspects, there are some common characteristics in the developing countries which are objective obstacles to a successful implementation of IT. In most of the countries it is very difficult for the authorities to choose an optimum inflation rate (i.e. the base of the target). Although it is a common opinion that the range of inflation should be higher than it is in the advanced economies, it is still considered to be somewhat arbitrary. Another problem is the speed for achieving the target. Since most of these countries need first to reduce the inflation down to acceptable levels, the question is how to proceed after that. 
There is a wide spread opinion that the better approach is to choose a longer horizon. The choice of price index is even more problematic, since there are more shocks affecting price and inflation. On the other hand, controlling the prices is a common practice in most developing countries. This makes the process of inflation forecasting more difficult, since all the factors regarding the change in prices should be taken into account.

Masson et al. (1997) provide an interesting experiment. They prepared a questionnaire to obtain qualitative information regarding the general operating procedures of the monetary policy and the importance of inflation as a target chosen by the Central Bank. From 150 developing and transition economies, only five were identified as satisfying the condition of presently conducting their monetary policy in the scope of inflation targeting framework or as being potential candidates for future adoption. These five countries are Chile, Colombia, Indonesia, Mexico and the Philippines. To assess their performance the authors adopt a scoring procedure in which the benchmark score for a "typical" inflation targeting country is intended to be 100 . They found that Chile is the country which is the closest to conducting monetary policy consistent within the IT framework - its scores are $25 \%$ below the benchmark. Colombia, Mexico and Indonesia are in the second group with $60 \%$ below the benchmark. The Philippines monetary policy least resembles the benchmark. Although this procedure has many shortcomings, it can still be used to show one important result. At the time this analysis was conducted (end of 1996), no developing country implemented IT in a fully consistent way in its monetary policy.

Morande and Schmidt-Hebbel (2000) present some of the results from adopting IT in Chile. Monetary authorities in Chile decided to adopt inflation targeting in the early 1990s, after failing twice with the choice of the exchange rate as a nominal anchor. The Chilean case can be considered as a unique one, because IT was adopted when inflation was still very high - around $20 \%$. After a gradual and flexible implementation, inflation was reduced without output costs until 1998, when the Asian crises brought the first recession since 1982. After ten years experience, the inflation rate was reduced to $2.3 \%$.

The Israeli experience is presented in Leiderman and Bar-Or (2000) and Leiderman and Bufman (2000). This is quite an instructive case, since for a short period Israel has two nominal anchors - inflation and exchange rate. "Since 1991, the Bank of Israel has announced a year in advance a rate of crawl of the central parity of the exchange rate band, approximately equal to the difference between the inflation target and the estimate of the inflation rate of the Israel's main trade partners". This period is characterized by extreme inflows of foreign capital, which turned out to be one of the main reasons for the lack of consistency between the inflation and the exchange rate targets. This forced the Bank of Israel to confront the levels of interest rate, consistent with the target. The dilemma was resolved quite often in favor of the inflation target. The conclusion is that a clear objective has to be set among different targets.

Poland's experience as an advanced transition economy is also quite interesting. Though having some different patterns, Poland adopted inflation targeting in 1998. It had the same problems experienced by Israel for a couple of years. More interesting here is the lack of a firm statistical linkage between inflation and monetary policy instruments (such as policy interest rates), discussed by Christoffersen and Wescott (1999).

Carstens and Werner (1999) and Galindo and Ros (2005) argue that Mexico's experience has shown that the floating exchange rate regime adopted by the monetary authorities was not an obstacle for the implementation of inflation targeting. Instead, its contribution was significant regarding the capital movements (short-term inflows) and external shocks.

Debelle and Lim (1998) in the case of the Philippines and Hoffimaister (1999) in the case of Korea, analyzing the necessary preconditions for adopting inflation targeting, point out that both countries need to make some changes. Namely, they consider the fact that the target should be made clear, especially regarding the exchange rates, as well as implementing the required refinement of the forecasting framework.

Jonas and Mishkin (2003) summarize the experience of the Czech Republic, Poland and Hungary. All three countries managed to achieve the targeted inflation within three to four years after introducing the IT policy. Baldursson and Hall (2008) show that the policy of IT introduced in 2001 was not successful in Iceland. The economy was plagued with highly volatile demand and exchange rate, and the inflation rose to $12 \%$ in 2008 .

\section{Conclusions}

The two major prerequisites for successful adoption of inflation targeting are: independence of the Central Bank to choose the instrument and absence of commitment to other targets (wages and exchange rates). Every country, satisfying these requirements can conduct monetary policy, consistent with inflation targeting. It can be defined as a framework with an explicitly chosen future inflation target, together with a model for predicting inflation and procedure for adjusting the instrument in case the target differs from the forecast. The first industrialized 
countries implementing this framework have shown a very promising performance. They start from low (less than $10 \%$ ) inflation rates, flexible exchange rates and independent actions of the Central Bank in choosing instruments. All these conditions are rarely present in the developing countries. This suggests that simpler monetary policy frameworks are preferable during the process of stabilization and market orientation. It is quite possible that inflation targeting can become a good option for developing countries, when the other nominal anchors are less feasible.

While being a promising device, providing transparency in conducting monetary policy, inflation targeting should not be taken out of the scope of its macro foundations.

\section{References}

Aninat, E. (2000). High Level Seminar on Implementing Inflation Targets. [Online] Available: http://www.imf.org/external/np/speeches/2000/032100.htm (November 10, 2011)

Archer, D. (2000). Inflation Targeting in New Zealand. IMF, Washington, D. C. [Online] Available: http://www.imf.org/external/pubs/ft/seminar/2000/targets/archer.htm (November 10, 2011)

Arndt, S. W. (2006). Regional currency arrangements in North America. International Economics and Economic Policy, 3(3/4), 265-280. http://dx.doi.org/10.1007/s10368-006-0059-z

Baldursson, F. M., \& Hall, A. (2008). Out of reach? Convergence to an Inflation Target in the Central Bank of Iceland's Macroeconomic Model. Tímarit um viðskipti og efnahagsmál Special Issue 2008, 83-106.

Bernanke, B., \& Mishkin, F. (1997). Inflation Targeting: A New Framework for Monetary Policy? Journal of Economic Perspectives, 11, 97-116. http://dx.doi.org/10.1257/jep.11.2.97

Bernanke, B., \& Woodford, M. (1996). Inflation Forecast and Monetary Policy. NBER Working Paper 6157. [Online] Available: http://www.nber.org/papers/w6157.pdf (November 10, 2011)

Bernanke, B., \& Woodford, M. (2005). Inflation Targeting Debate. (1st ed.). Chicago: University of Chicago Press.

Bernanke, B., Laubach, T., Mishkin, F. S., \& Posen, A. (1999). Inflation Targeting: Lessons from the International Experience. (1st ed.). Princeton: Princeton University Press.

Blejer, M. I., Ize, A, Leone, A. M., \& Werlang, S. (Eds.) (2000). Inflation Targeting in Practice: Strategic and Operational Issues and Application to Emerging Market Economies. IMF. [Online] Available: http://www.imf.org/external/pubs/ft/seminar/2000/targets/stratop.htm (November 10, 2011)

Bulir, A., Šmídková, E., Kotlan, V., \& Navratil, D. (2007). Inflation Targeting and Communication: Should the Public Read Inflation Reports or Tea Leaves? [Online] Available: http://www.cnb.cz/miranda2/export/sites/www.cnb.cz/en/research/research_publications/cnb_wp/download/cnb wp_2007_14.pdf (January 22, 2012)

Carstens, A., \& Werner, A. (1999). Mexico's Monetary Policy Framework under a Floating Exchange Rate Regime. [Online] Available: http://www.imf.org/external/pubs/ft/seminar/2000/targets/carstens.pdf (January 22, 2012)

Christoffersen, P. F., \& Wescott, R. F. (1999). Is Poland Ready for Inflation Targeting. IMF Working Paper 99/41. [Online] Available: http://www.imf.org/external/pubs/ft/wp/1999/wp9941.pdf (December 12, 2011)

Clarida, R., Gali, J., \& Gertler, M. (1999). The Science of Monetary Policy: A New Keynesian Perspective. Journal of Economic Literature, 37, 1661-1707. http://dx.doi.org/10.1257/jel.37.4.1661

Clarida, R., Gali, J., \& Gertler, M. (2000). Monetary Policy Rules and Macroeconomic Stability: Evidence and Some Theory. Quarterly Journal of Economics, 115, 147-180. http://dx.doi.org/10.1162/003355300554692

Debelle, G. (1997). Inflation Targeting in Practice. IMF Working Paper 97/35. [Online] Available: http://www.imf.org/external/pubs/ft/wp/wp9735.pdf (December 12, 2011)

Debelle, G. (2000). Inflation Targeting and Output Stabilization in Australia. In Blejer, M. I., A. Ize., A. M. Leone., \& Werlang, S. (Eds.), Inflation Targeting in Practice: Strategic and Operational Issues and Application to Emerging Market Economies. IMF. [Online] Available: http://www.imf.org/external/pubs/ft/seminar/2000/targets/strach6.pdf (January 22, 2012)

Debelle, G., \& Lim, C. H. (1998). Preliminary Considerations of an Inflation Targeting Framework for the Philippines. IMF Working Paper 98/39. [Online] Available: http://www.imf.org/external/pubs/ft/wp/wp9839.pdf (January 22, 2012) 
Ersel, H., \& Özatay, F. (2007). Fiscal Dominance and Inflation Targeting: Lessons from Turkey. Working Paper (Sabanc1 University, İstanbul, Turkey). [Online] Available: http://fatih.ozatay.etu.edu.tr/ersel_ozatay.pdf (December 12, 2011)

Freedman, C., Deputy Governor, Bank of Canada (2000). The Framework for the Conduct of Monetary Policy in Canada: Some Recent Developments. [Online] Available: http://www.imf.org/external/pubs/ft/seminar/2000/targets/freedmn1.htm (January 22, 2012)

Friedman, B. M. (2004). Why the Federal Reserve Should Not Adopt Inflation Targeting. International Finance, 7, 129-136. http://dx.doi.org/10.1111/j.1367-0271.2004.00131.x

Galindo, L. M., \& Ros, J. (2005). Alternatives to inflation targeting in Mexico. [Online] Available: http://www.networkideas.org/feathm/oct2007/pdf/Galindo_Ros.pdf (December 12, 2011)

Goodfriend, M. (2000). Maintaining low inflation: Rational and Reality. In Blejer, M. I., A. Ize., A. M. Leone., \& S. Werlang (Eds.), Inflation Targeting in Practice: Strategic and Operational Issues and Application to Emerging Market Economies. [Online] Available: http://www.imf.org/external/pubs/ft/seminar/2000/targets/strach2.pdf (January 12, 2012)

Haldane, A. (1998). On Inflation Targeting in the United Kingdom. Scottish Journal of Political Economy, 45, 1-30. http://dx.doi.org/10.1111/1467-9485.00079

Hoffimaister, A. W. (1999). Inflation Targeting in Korea: An Empirical Exploration. IMF Working Paper 99/7. [Online] Available: http://www.imf.org/external/pubs/ft/wp/1999/wp9907.pdf (January 22, 2012)

Jonas, J., \& Mishkin, F. S. (2003). Inflation Targeting in Transition Countries: Experience and Prospects. NBER Working Paper 9667. [Online] Available: http://www.nber.org/papers/w9667.pdf (January 22, 2012)

Jonsson, G. (1999). The Relative Merits and Implications of Inflation Targeting for South Africa. IMF Working Paper 99/116. [Online] Available: http://www.imf.org/external/pubs/ft/wp/1999/wp99116.pdf (January 22, 2012)

Koeppl, T. (2009). How Flexible Can Inflation Targeting Be? Suggestions for the Future of Canada's Targeting Regime. C. D. Howe Institute Commentary, No 293. [Online] Available: http://www.cdhowe.org/pdf/commentary_293.pdf (January 22, 2012)

Leiderman, L., \& Bar-Or, H. (2000). Monetary Policy Rules and Transmission Mechanisms under Inflation Targeting in Israel. Research Department, Bank of Israel. [Online] Available: http://www.imf.org/external/pubs/ft/seminar/2000/targets/leidermn.pdf (January 22, 2012)

Leiderman, L., \& Bufman, G. (2000). Inflation Targeting under a Crawling Band Exchange Rate Regime: Lessons from Israel. In Blejer, M. I., A. Ize, A. M. Leone, \& S. Werlang (Eds.), Inflation Targeting in Practice: Strategic and Operational Issues and Application to Emerging Market Economies. [Online] Available: http://www.imf.org/external/pubs/ft/seminar/2000/targets/strach9.pdf (January 22, 2012)

Leiderman, L., \& Svensson, L. E. O. (1995). Inflation targets. CEPR, London.

Masson, P. R., Savastano, M., \& Sharma, S. (1997). The Scope for Inflation Targeting in Developing Countries. IMF Working Paper 97/130. [Online] Available: http://www.imf.org/external/pubs/ft/wp/wp97130.pdf (January 22, 2012)

McCallum, B. T. (1997a). Crucial Issues Concerning Central Bank Independence, Journal of Monetary Economics, 39, 99-112. http://dx.doi.org/10.1016/S0304-3932(97)00007-X

McCallum, B. T. (1997b). Issues in the Design of Monetary Policy Rules. NBER Working Paper 6016. [Online] Available: http://www.nber.org/papers/w6016.pdf (January 22, 2012)

McCallum, B. T. (2000). Alternative Monetary Policy Rules: A Comparison with Historical Setting for the United States, the United Kingdom and Japan. NBER Working Paper 7725. [Online] Available: http://www.nber.org/papers/w7725.pdf (January 22, 2012)

McCallum, B. T. (2007). Inflation Targeting for the United States? Cato Journal, 27, 261-271. [Online] Available: http://www.cato.org/pubs/journal/cj27n2/cj27n2-14.pdf (January 22, 2012)

Mishkin, F. C. (2004). Why the Federal Reserve Should Adopt Inflation Targeting. International Finance, 7 , 117-127. http://dx.doi.org/10.1111/j.1367-0271.2004.00132.x

Morande, F., \& Schmidt-Hebbel, K. (2000). Monetary Policy and Inflation Targeting in Chile. In Blejer, M. I., Ize, A., Leone, A. M., \& Werlang, S. (eds.), Inflation Targeting in Practice: Strategic and Operational Issues and Application to Emerging Market Economies. IMF. [Online] Available: 
http://www.imf.org/external/pubs/ft/seminar/2000/targets/strach8.pdf (January 22, 2012)

Nakamura, E., \& Steinsson, J. (2008). Five Facts about Prices: A Reevaluation of Menu Cost Models. The Quarterly Journal of Economics, 123, 1415-1464. http://dx.doi.org/10.1162/qjec.2008.123.4.1415

Orphanides, A., \& Williams, J. C. (2004). Imperfect Knowledge, Inflation Expectations and Monetary Policy. In Ben Bernanke and Michael Woodford (eds.), The Inflation Targeting Debate. Chicago: University of Chicago Press.

Orphanides, A., \& Williams, J. C. (2006). Monetary Policy with Imperfect Knowledge. Journal of the European Economics Association, 4, 366-375. http://dx.doi.org/10.1162/jeea.2006.4.2-3.366

Orphanides, A., \& Williams, J. C. (2007). Inflation Targeting under Imperfect Knowledge. FRBSF Economic Review 2007, 1-23. [Online] Available: http://www.frbsf.org/publications/economics/review/2007/er1-23.pdf (January 22, 2012)

Stiglitz, J. E. (2008). The Failure of Inflation Targeting. Project Syndicate. [Online] Available: http://www.project-syndicate.org/print_commentary/stiglitz99/English (January 22, 2012)

Svensson, L. E. O. (1997). Inflation Forecast Targeting: Implementing and Monitoring Inflation Targets. European Economic Review, 41, 1111-1146. http://dx.doi.org/10.1016/S0014-2921(96)00055-4

Svensson, L. E. O. (1999). Inflation Targeting as a Monetary Policy Rule. Journal of Monetary Economics, 43, 607-654. http://dx.doi.org/10.1016/S0304-3932(99)00007-0

Svensson, L. E. O. (2008). Inflation Targeting. In the New Palgrave Dictionary of Economics. (2nd ed.), New York: Macmillan.

Walsh, C. (2008). Inflation targeting: What have we learned? [Online] Available: http://people.ucsc.edu/ walshc/MyPapers/Kuszczak_Lecture_20090131.pdf (January 22, 2012)

White, L. H. (2007). What Type of Inflation Target? Cato Journal, 27, 283-288. [Online] Available: http://www.cato.org/pubs/journal/cj27n2/cj27n2-16.pdf (January 22, 2012) 
Table 1. Economies with Explicit Inflation Targeting Framework: Selected features

\begin{tabular}{|c|c|c|c|c|}
\hline Country & $\begin{array}{c}\text { Date of } \\
\text { Adoption }\end{array}$ & $\begin{array}{c}\text { Target Rate and } \\
\text { Horizon }\end{array}$ & Price Index & Other Details \\
\hline $\begin{array}{l}\text { New } \\
\text { Zealand }\end{array}$ & March 1990 & $\begin{array}{l}0-2 \% \text { through the } \\
5 \text {-year tenure of the } \\
\text { Governor of the } \\
\text { Reserve Bank }\end{array}$ & $\begin{array}{l}\text { CPI, excluding interest } \\
\text { cost components, } \\
\text { indirect taxes and } \\
\text { subsidies, Government } \\
\text { charges, and significant } \\
\text { price effects from } \\
\text { changes in the terms of } \\
\text { trade }\end{array}$ & \\
\hline Canada & February 1991 & $1-3 \%$ through 1998 & $\begin{array}{l}\text { CPI, excluding food, } \\
\text { energy, and the effect of } \\
\text { indirect tax changes. }\end{array}$ & $\begin{array}{l}\text { Successful in } \\
\text { keeping infl. at 2\% } \\
\text { until } 2011\end{array}$ \\
\hline $\begin{array}{l}\text { United } \\
\text { Kingdom }\end{array}$ & October 1992 & $\begin{array}{l}\text { Lower half of the } \\
1-4 \% \text { range by } \\
\text { spring } 1997,2 \% \text { or } \\
\text { less thereafter. }\end{array}$ & $\begin{array}{l}\text { Retail Price Index, } \\
\text { excluding mortgage } \\
\text { interest payment (RPIX) }\end{array}$ & ( \\
\hline Sweden & January 1993 & $\begin{array}{l}2 \%+/-1 \% \text { in } 1996 \\
\text { and beyond. }\end{array}$ & CPI & . \\
\hline Finland & February 1993 & $\begin{array}{l}\text { About } 2 \% \text { in } 1996 \\
\text { and beyond. }\end{array}$ & $\begin{array}{l}\text { CPI, excluding indirect } \\
\text { taxes, Government } \\
\text { subsidies, house prices, } \\
\text { and mortgage interest } \\
\text { payments }\end{array}$ & \\
\hline Australia & $\begin{array}{l}\text { April } 1993 \\
\text { (approx.) }\end{array}$ & $\begin{array}{l}\text { Underlying } \\
\text { inflation } 2-3 \% \text {, on } \\
\text { average, over the } \\
\text { economic cycle. }\end{array}$ & $\begin{array}{l}\text { CPI, excluding the } \\
\text { impact of interest rates } \\
\text { on mortgage and other } \\
\text { volatile price items. }\end{array}$ & \\
\hline Iceland & March 2001 & $2.5 \%$ & CPI & $\begin{array}{l}\text { Unsuccessful, } \\
\text { inflation has reached } \\
12 \% \text { in } 2008 ; \\
\text { volatile demand and } \\
\text { exchange rate }\end{array}$ \\
\hline Norway & March 2001 & $2.5 \%$ or less & CPI & \\
\hline Spain & $\begin{array}{l}\text { November } \\
1994\end{array}$ & $\begin{array}{l}\text { Less than } 3 \% \text { by } \\
1997,2 \% \text { by } 1998 .\end{array}$ & CPI & \\
\hline $\begin{array}{l}\text { Czech } \\
\text { Republic }\end{array}$ & $\begin{array}{l}\text { December } \\
1997\end{array}$ & $\begin{array}{l}2-4 \% ; 1 \% \text { band in } \\
1998 \text { \& } 1999 ; 2 \% \\
\text { band after that }\end{array}$ & $\begin{array}{l}\text { CPI, excluding the } \\
\text { movement in regulated } \\
\text { prices }\end{array}$ & $\begin{array}{l}\text { Target achieved in } \\
2005\end{array}$ \\
\hline Poland & June 1998s & $\begin{array}{l}\text { less than } 4 \%, 1.2 \% \\
\text { band }\end{array}$ & Broad CPI & $\begin{array}{l}\text { Target achieved in } \\
2003\end{array}$ \\
\hline Hungary & August 2001 & $\begin{array}{l}4.5 \% \text { for } 2002 . \\
3.5 \% 2003 \text { and } \\
2004 ; 2 \% \text { after, } 1 \% \\
\text { band }\end{array}$ & Headline CPI & $\begin{array}{l}\text { Target achieved in } \\
2004-05\end{array}$ \\
\hline Turkey & January 2006 & $\begin{array}{l}5 \% \text { for } 2006,4 \% \\
\text { after that }\end{array}$ & Headline CPI & $\begin{array}{l}\text { Implicit IT between } \\
2001 \& 2005\end{array}$ \\
\hline Mexico & January 1995 & $3 \%$ with $1 \%$ band & CPI & Target met in 2003 \\
\hline Chile & January 1991 & $2-4 \%$ & CPI & \\
\hline Brazil & June 1999 & $4.5 \%, 2 \%$ band & CPI & \\
\hline Colombia & Sept. 1999 & $5 \%, 0.5 \%$ band & $\mathrm{CPI}$ & \\
\hline Philippines & January 2002 & $5-6 \%$ & CPI & \\
\hline Peru & January 2002 & $2.5 \%, 1 \%$ band & $\mathrm{CPI}$ & \\
\hline Thailand & May 2000 & $2 \%$ & CPI and "core"inflation & \\
\hline Korea & April 1998 & $2.5-3.5 \%$ & CPI & \\
\hline Israel & January 1992 & $1-3 \%$ & CPI & \\
\hline South Africa & Feb. 2000 & $3-6 \%$ & CPI & \\
\hline
\end{tabular}

Sources: New Zealand, Canada, UK, Finland, Australia and Spain (Masson et al., 1997); the Czech Republic and Hungary (Jonas and Mishkin, 2003; Bulir et al., 20071); Iceland (Baldursson and Hall, 2008); Canada (Koeppl, 2009; Masson et al., 1997); Turkey (Ersel and Özatay, 2007); Mexico (Galindo and Ros, 2005; Carstens and Werner); Korea (Hoffmaister, 1999); South Africa (Jonsson, 1999). 